\title{
Perjanjian Sewa Menyewa Mobil yang Menimbulkan Wanprestasi di Kabupaten Bantul
}

\author{
Fredi Ahmad Fadilah ${ }^{1}$, Endang Heriyani ${ }^{2}$ \\ ${ }^{1,2}$ Program Studi Hukum, Fakultas Hukum, Universitas Muhammadiyah Yogyakarta, Indonesia \\ Jl. Brawijaya, Tamantiro, Kasihan, Bantul, Yogyakarta \\ E-mail: ${ }^{1}$ fredi.ahmad.2015.@law.umy.ac.id; ${ }^{2}$ endangheriyani@umy.ac.id
}

\section{Info Artikel}

Diajukan: 22-02-2020

Direview: 26-03-2020

Direvisi: $30-03-2020$

Diterima: 01-04-2020

DOI: $10.18196 / \mathrm{mls} . v 1 i 2.8346$

\begin{abstract}
Abstrak
Perjanjian sewa menyewa pada perusahaan persewaan mobil sering terjadi wanprestasi. Tujuan dalam penelitian, yaitu mengetahui wanprestasi dan bentuk penyelesaian apabila terjadi wanprestasi pada perusahaan persewaan mobil yaitu CV. GH Tour and Travel, CV. Cahya Tour, dan CV. Mae Trans. Metode Penelitian: Jenis penelitian ini adalah penelitian hukum normatif-empiris. Teknik Pengumpulan Data menggunakan Metode Interview atau wawancara, observasi
\end{abstract} dan dokumentasi. Teknik Analisis Data menggunakan teknik kualitatif, penelitian ini menggunakan metode silogisme dan interpretasi. Hasil penelitian menunjukkan Perjanjian Sewa Menyewa Mobil Yang Menimbulkan Wanprestasi di Kabupaten Bantul yaitu Penyewa merusak objek sewa. Penyelesaiannya dilakukan dengan cara meminta uang ganti sewa atas biaya servis kendaraan selama berada dalam masa perbaikan. Penyewa terlambat mengembalikan objek kendaraan. Penyelesaiannya dilakukan dengan cara memberikan biaya denda kepada pihak penyewa, perhitungan untuk keterlambatan dihitung setiap jamnya dan besarnya denda adalah $10 \%$ dari harga sewa mobil yang disewa. Penyewa menyewakan ulang obyek kendaraan. Penyelesaiannya dilakukan dengan meminta biaya kerugian dan meminta uang hasil dari penyewa yang mengulang sewakan obyek sewa kepada pihak ketiga

Kata kunci: kendaraan bermotor, perjanjian sewa menyewa, wanprestasi

\section{Pendahuluan.}

Yogyakarta sebagai ikon pariwisata banyak dikenal di Indonesia, maupun Mancanegara dan menyita wisatawan lokal dan internasional. Adapun wisata yang dapat dikunjungi di kota ini bertebaran di berbagai sudut Kota, Desa dan Pantai. Wisata di Yogyakarta menjadi pusat yang penting di masa kini. Para wisatawan dapat berkunjung untuk menikmati suasana wisata yang menjadi objek keindahan. Hal demikian menjadi titik keistimewaan tersendiri bagi kota yang dinobatkan menjadi Daerah Istimewa Yogyakarta di masa pemerintahan Soekarno. ${ }^{1}$

Adanya sewa mobil untuk kepentingan tour menjadi hal yang penting bagi wisatawan. Hal ini pula dijadikan suatu kesempatan oleh beberapa orang yang memiliki modal untuk membuka jasa rental mobil sebagai keperluan wisatawan. Sewa mobil

\footnotetext{
${ }^{1}$ Wahyu Santoso Langgeng , 2016, Keistimewaan Yogyakarta dari Sudut Pandang Geomorfologi, Yogyakarta, Gadjah Mada University Press, hlm. 2.
} 
yang dilakukan oleh pihak jasa mobil rental, memiliki syarat dan aturan tersendiri. Adanya syarat tersebut untuk saling menjaga hubungan baik satu sama lainnya, antara penyewa dan pihak jasa yang menyewakan.

Perjanjian yang dilakukan tersebut tidak ada unsur paksaan namun lebih kepada perjanjian sukarela oleh kedua pihak. Dalam hal perjanjian kedua belah pihak terjalin suatu kerjasama yang saling percaya sehingga tidak ada pihak yang dirugikan. Sesuai dengan Kitab Undang-Undang Hukum Perdata, Pasal 1548, yang menjelaskan tentang rentang waktu dalam melakukan sewa-menyewa.

CV. GH Tour and Travel, CV. Cahya Tour, dan CV. Mae Trans, yang berada di Yogyakarta menyediakan jasa penyewaan atau rental mobil untuk wisatawan atau masyarakat yang tinggal di Yogyakarta. Ketiga rental mobil tersebut memiliki basis bagus dalam memberikan layanan yang terbaik bagi para konsumen yang ingin menyewa mobil. Ketiga rental tersebut pula menyediakan sopir bagi penyewa yang ingin menyewa tentu dengan biaya tambahan sopir.

Sebagai jasa rental mobil, ketiganya juga terdapat beberapa masalah terkait wanprestasi. Persoalan yang kadang terjadi, mobil kembali dalam keadaan rusak, jam yang disepakati tidak sesuai, ataupun mobil dibawa oleh pihak yang tidak bertanggung jawab. Dengan demikian, tentu terjadi kerugian pihak tersebut. Adanya peristiwa tersebut menjadi wanprestasi. Wanprestasi ini berkenaan tidak terpenuhinya atau lalai melaksanakan kewajiban (prestasi) sebagaimana yang ditentukan dalam perjanjian yang dibuat oleh kedua belah pihak (antara kreditor dengan debitor). ${ }^{2}$

Berdasarkan beberapa unsur tersebut dalam suatu perjanjian sewa menyewa pihak yang tidak melaksanakan kewajibannya seperti yang termuat dalam isi perjanjian maka dapat dikatakan sebagai wanprestasi. Kondisi demikian akan sangat mempengaruhi bisnis sewa menyewa mobil yang ada di Yogyakarta yaitu CV. GH Tour and Travel, CV. Cahya Tour, dan CV. Mae Trans, karena hal tersebut dapat menimbukan kerugian bagi pihak yang menyewakan. Penelitian ini akan mengkaji terkait perjanjian sewa menyewa mobil yang menimbulkan wanprestasi di Kabupaten Bantul.

\section{Metode Penelitian.}

\subsection{Jenis Penelitian}

Jenis penelitian ini adalah penelitian hukum normatif-empiris. Menurut Abdulkadir Muhammad yang dimaksud sebagai penelitian hukum normatif-empiris (applied law research) merupakan penelitian yang menggunakan studi kasus hukum normatif-empiris berupa produk perilaku hukum ${ }^{3}$.

\footnotetext{
${ }^{2}$ Subekti, 1984, Hukum Perjanjian, Jakarta, Intermasa, hlm. 45.

${ }^{3}$ Abdulkadir Muhammad, 2004, Hukum dan Penelitian Hukum Cet-1, PT Citra Aditya Bakti, Bandung, hlm.

52.
} 


\subsection{Sumber Data}

Penelitian ini bersumber pada studi kepustakaan sehingga jenis data yang akan dikaji adalah data sekunder namun tidak menutup kemungkinan melakukan penelitian lapangan dengan mengkaji data primer. Di dalam penelitian ini jenis data sekunder yang peneliti gunakan terdiri dari:

\section{Bahan Hukum Primer}

Bahan hukum primer adalah bahan hukum yang sifatnya mengikat dan diperoleh dari penelitian kepustakaan yang berhubungan dengan masalah yang diteliti. ${ }^{4}$ Bahan hukum primer yang digunakan dalam penelitian ini adalah: KUHPerdata (Kitab Undang-Undang Hukum Perdata);

\section{Bahan Hukum Sekunder}

Bahan hukum sekunder adalah bahan hukum yang bersifat tidak mengikat dan diperoleh dari penelitian kepustakaan untuk mendukung hukum primer. ${ }^{5}$ Hal ini terdiri dari buku-buku tentang hukum perjanjian, yaitu buku-buku tentang hukum perjanjian sewa menyewa, asas-asas hukum, jurnal-jurnal tentang perjanjian sewa menyewa.

\section{Bahan Hukum Tersier}

Bahan hukum tersier adalah bahan hukum yang memberikan penjelasan terhadap bahan hukum primer dan sekunder, seperti Kamus Hukum, Ensiklopedia.

\subsection{Lokasi Penelitian}

Adapun lokasi penelitian dalam penelitian ini, yaitu di Kabupaten Bantul. Tepatnya, pada tiga rental mobil: CV. GH Tour and Travel, CV. Cahya Tour, dan CV. Mae Trans.

\subsection{Teknik Pengambilan Sampel}

Teknik pengambilan sampel dalam penelitian ini yaitu menggunakan Purposive sampling. Purposive sampling adalah teknik pengambilan sampel sumber data dengan pertimbangan tertentu. Pertimbangan tertentu ini misalnya orang tersebut yang dianggap tahu tentang apa yang kita harapkan atau mungkin dia sebagai penguasa sehingga akan memudahkan peneliti menjelajahi obyek atau situasi yang diteliti. Atau dengan kata lain pengambilan sampel diambil berdasarkan kebutuhan penelitian ${ }^{6}$.

\subsection{Teknik Pengumpulan Data}

Dalam penelitian ini, pengumpulan data dilakukan dengan beberapa cara, diantaranya :

\footnotetext{
4, Abdulkadir Muhammad, 2004, Hukum dan Penelitian Hukum Cet-1, PT Citra Aditya Bakti, Bandung, hlm. 52 .

${ }^{5}$ Ibid

${ }^{6}$ Sugiyono, 2014. Metode Penelitian Kuantitatif Kualitatif dan R\&D. Bandung: Alfabeta, hlm.15
} 


\section{Studi Dokumen}

Dokumen merupakan catatan peristiwa yang sudah berlalu, dapat berbentuk tulisan, gambar, atau karya-karya monumental dari seseorang. Dokumen yang berbentuk tulisan misalnya catatan harian, sejarah kehidupan, biografi, peraturan dan kebijakan. Dokumen yang berbentuk gambar misalnya foto, gambar hidup, skesta dan lain-lain. Dokumen yang berbentuk karya misalnya karya seni yang dapat berupa gambar, patung, film dan sebagainya. Studi dokumen merupakan pelengkap dari penggunaan metode observasi dan wawancara ${ }^{7}$

2. Wawancara

Metode Interview atau wawancara merupakan cara pengumpulan data menggunakan teknik wawancara secara mendalam (in-depth interview). Menurut Esterberg dalam bukunya Sugiyono mengemukakan bahwa wawancara adalah pertemuan dua orang untuk bertukar informasi dan ide melalui tanya jawab, sehingga dapat dikonstruksikan makna dalam suatu topik tertentu. Tipe wawancara yang digunakan dalam penelitian ini bersifat semi terstruktur (semi structure interview).

Tujuan dari wawancara jenis ini adalah untuk menemukan permasalahan secara lebih terbuka, di mana pihak yang diajak wawancara diminta pendapat dan ide- idenya.

\section{Observasi}

Metode observasi adalah suatu cara pengumpulan data dengan menggunakan indra, terutama pengamatan. Observasi dapat diartikan sebagai pencatat atau pengamatan terhadap gejala-gejala yang diselidiki dan juga dapat diartikan sebagai pencatat atau pengamatan bebas.

\subsection{Analisis Data}

Data yang diperoleh dalam penelitian ini dianalisis secara kualitatif, yaitu dengan mengumpulkan data, mengkualifikasikan kemudian menghubungkan teori yang berhubungan dengan masalah dan menarik kesimpulan untuk menentukan hasil.

Di dalam menarik suatu kesimpulan dalam penelitian ini menggunakan metode silogisme dan interpretasi. Penggunaan silogisme dalam penelitian hukum ini berpangkal pada pengajuan premis mayor dan kemudian diajukan premis minor, selanjutnya ditarik suatu simpulan atau conclusion ${ }^{8}$. Dalam logika silogistik untuk penalaran hukum, yang merupakan premis mayor adalah aturan hukum, sedangkan fakta hukum merupakan premis minor yang kemudian dari kedua premis tersebut ditarik kesimpulan.

\footnotetext{
${ }^{7}$ Ibid

${ }^{8}$ Peter Mahmud Marzuki, 2008, Penelitian Hukum, Kencana, Jakarta, hlm. 47
} 


\section{Hasil dan Pembahasan.}

Perjanjian sewa menyewa mobil yang menimbulkan wanprestasi di Kabupaten Bantul yaitu:

1. Merusak objek sewa.

Salah satu bentuk wanprestasi yang dilakukan oleh penyewa di CV. GH Tour and Travel yaitu penyewa merusak objek sewa, diduga tidak memiliki itikad baik setelah ditagih berulang kali tetapi selalu mengabaikan adalah penyewa mobil bernama bapak Randi untuk pemakaian selama tiga hari tetapi mobil sewa mengalami kerusakan karena penyewa tidak hati-hati sehingga yang menyebabkan kerusakan yang pada bagian mobil dan onderdil mobil dan harus diasuransikan selama 20 hari dimana hal tersebut tentu merugikan pihak rental secara materill maupun immateril karena mobil rental tidak dapat disewakan kepada pihak lain pada masa perbaikan berlangsung. Sesuai dengan syarat dan ketentuan yang telah dibuat oleh CV. GH Tour and Travel apabila terjadi kerusakan maka pihak penyewa menanggung biaya kerugian Rp.500.000,00. untuk klaim asuransi serta biaya penuh sewa selama mobil dalam perbaikan. Pihak penyewa menyewa mobil Toyota Innova all new Tahun 2018 dengan biaya sewa sebesar Rp.400.000,00. perharinya dan karena masa perbaikan hingga 20 hari maka Bapak Randi wajib membayar kerugian sebesar Rp 8.000.00,009.

Penyelesaian Wanprestasi dalam sewa menyewa mobil pada CV. GH Tour yaitu penyewa merusak objek sewa. Penyelesaiannya menurut pemilik rental CV. GH Tour and Travel yaitu mengganti, perincian ganti rugi yang harus dibayarkan pihak penyewa sebesar Rp. 8.500.000,00 adalah sebagai berikut:

a. Terdapat ketentuan dari asuransi mobil tersebut bahwa pemilik mobil menanggung kerugian sebesar Rp. 500.000,00 untuk setiap kejadian yang mendapat tanggungan asuransi. Artinya untuk memperbaiki mobil pemilik mobil hanya menanggung biaya sebesar Rp. 500.000,00 dan selebihnya akan menjadi tanggungan perusahaan asuransi. Maka biaya untuk klaim asuransi ini ditanggung oleh pihak penyewa.

b. Selama mobil diperbaiki dibengkel, maka penyewa harus membayar biaya sebagai pengganti keuntungan yang seharusnya diperoleh. Biaya yang dikenakan sebesar harga sewa sesuai dengan perjajian, Pemilik CV. GH Tour and Travel memperkirakan waktu perbaikan 20 hari dengan harga sewa Rp. 400.000,00. Per hari. Maka unttuk 20 hari penyewa harus membayar ganti kerugian sebesar Rp. 8.000.000,00. Pembayaran sebesar Rp. 8.500.000,00 tersebut menunjukan bahwa kedua ketentuan mengenai ganti rugi dalam perjanjian tidak diberlakukan secara ketat. Penyewa tidak dituntut untuk memperbaiki kerusakan atau

\footnotetext{
${ }^{9}$ Wawancara dengan Bapak Ilham selaku Pimpinan CV. GH Tour and Travel pada tanggal 1 November 2019.
} 
membayar sebesar kerusakan yang terjadi, melainkan hanya di wajibkan menanggung biaya selama masa perbaikan asuransi mobil ${ }^{10}$.

Berdasarkan hasil wawancara dengan direktur CV. GH Tour and Travel dalam hal penyelesaian sengketa terhadap wanprestasi oleh penyewa sejauh ini masih dilakukan secara kekeluargaan atau dilakukan secara non litigasi, yaitu penyelesaian perkara diluar pengadilan dengan mengedepankan rasa kebersamaan dan kekeluargaan antara pihak yang menyewakan dengan pihak penyewa karena pihak penyewa rata-rata masih memiliki i’tikad baik untuk tidak menghilang begitu saja ${ }^{11}$.

\section{Terlambat mengembalikan objek kendaraan}

Wanprestasi yang terjadi dalam perjanjian sewa menyewa yang dilakukandi CV. Cahya Tour yaitu penyewa terlambat mengembalikan objek kendaraan, pihak penyewa seharusnya melakukan pengembalian mobil pada malam hari tetapi mundur dan pihak rental memberikan toleransi waktu sampai 2 jam akan tetapi pihak penyewa masih saja melakukan wanprestasi. CV. Cahya Tour dalam menyelesaikan sengketa wanprestasi berupa keterlambatan menggunakan cara negosiasi atau menggunakan cara kekeluargaan, perhitungan untuk keterlambatan dihitung setiap jam nya dan besarnya denda adalah $10 \%$ dari harga sewa mobil yang disewa ${ }^{12}$.

Penyelesaian Wanprestasi dalam sewa menyewa mobil pada CV. Cahya Tour yaitu penyewa terlambat mengembalikan objek kendaraan. Penyelesaianya yaitu pihak penyewa contohnya menyewa mobil APV dengan harga sewa Rp300.000/24 jam dan melakukan keterlambatan pengembalian mobil sewa selama 5 jam perhitungannya adalah $10 \%$ x Rp 300.000 x 5jam = Rp 150.000, jadi pihak penyewa membayar ganti rugi keterlambatan $\mathrm{Rp} 150.000$ karena keterlambatan 5jam apabila terlambat 1 jam hanya membayar Rp30.000 ${ }^{13}$. CV. Cahya Tour dalam menyelesaikan sengketa wanprestasi berupa keterlambatan menggunakan cara negosiasi atau menggunakan cara kekeluargaan, perhitungan untuk keterlambatan dihitung setiap jam nya dan besarnya denda adalah 10\% dari harga sewa mobil yang disewa. Cara penyelesaianya dengan memberikan Denda untuk tiap jamnya adalah $10 \%$ yang diberikan pihak rental untuk semua jenis mobil dan harus dibayarkan apabila terlambat mengembalikan mobil sesuai dengan lama keterlambatan ${ }^{14}$.

3. Penyewa menyewakan ulang obyek kendaraan.

\footnotetext{
${ }^{10}$ Wawancara dengan Bapak Ilham selaku Pimpinan CV. GH Tour and Travel pada tanggal 1 November 2019.

${ }^{11}$ Ibid

${ }^{12}$ Wawancara dengan Bapak Albertus okki setiawan selaku Pimpinan CV. Cahaya Tour pada tanggal 3 November 2019.

${ }^{13} \mathrm{Ibid}$

${ }^{14} \mathrm{Ibid}$
} 
Wanprestasi yang terjadi dalam perjanjian sewa menyewa yang dilakukandi CV. Mae Trans yaitu penyewa menyewakan ulang obyek kendaraan Berdasarkan hasil wawancara dengan pihak CV. Mae Trans yaitu adanya tindakan yang melanggar atau dilarang menurut perjanjian dan tidak sesuai dengan apa yang diperjanjian antara pihak CV. Mae Trans dengan penyewa yaitu mengenai bentuk perjanjian yang dilakukan dengan pihak CV. Mae Trans adalah melakukan apa yang menurut perjanjian dilarang dalam hal ini penyewa menyewakan ulang objek sewa yaitu 1 (satu) unit mobil Daihatzu xenia 2017 dengan warna silver dalam hal ini penyewa datang langsung ketempat CV. Mae Trans dan penyewa juga telah membaca dan menyepakati apa yang ada dalam isi perjanjian yang secara tertulis telah dibuat dengan pihak CV. Mae Trans secara atau dengan lepas kunci. Dengan ketentuan salah satunya menyewa mobil kepada pihak CV. Mae Trans selama 1 (satu) bulan atau 30 (tiga puluh) hari, yang mana mobil tersebut di sewa untuk di gunakan sebagai sarana transportasi demi kelancaran usaha yang baru didirikan oleh penyewa dengan hanya melakukan pembayaran secara penuh dari total harga sewa keseluruhan waktu sewa ${ }^{15}$. Dari Ketentuan tersebut, telah diatur didalam Pasal 1559 Kitab Undang-Undang Hukum Perdata yang menyatakan bahwa penyewa, jika tidak diizinkan, tidak boleh menyalahgunakan barang yang disewanya atau melepaskan sewanya kepada orang lain, atas ancaman pembatalan persetujuan sewa dan penggantian biaya, kerugian dan bunga sedangkan pihak yang menyewakan, setelah pembatalan itu, tidak wajib menaati persetujuan ulang sewa itu. Jika yang disewa itu berupa sebuah mobil yang dipakai sendiri oleh penyewa, maka dapatlah ia atas tanggung jawab sendiri menyewakan sebagian kepada orang lain jika hak itu tidak dilarang dalam persetujuan.

Upaya perlindungan hukum secara yuridis mengenai perbuatan mengulang sewakan telah sedemikian diatur pada sistem hukum keperdataan di Indonesia. Pada ketentuan KUHPerdata tentang sewa-menyewa dalam Pasal 1559 yaitu pihak penyewa tidak diperbolehkan mengulang sewakan barang yang di sewakan maupun melepasakan sewanya kepada seorang lain, selama ketentuan ini tidak dilarang di dalam perjanjian antara pihak yang mnyewakan dan pihak penyewa. Akan tetapi kenyataan masih saja terdapat penyewa yang mengalihakannya kepada pihak ketiga atau pun orang lain tanpa sepengatahuan atau seizin dan sepertujuan dari pihak yang menyewakan.

Pada perjanjian sewa-menyewa mobil baik dalam bentuk tertulis maupun tidak tertulis, aturan dalam Pasal1559 KUHPerdata jelas tidak memperbolehkan mengalihkan sewa maupun melepaskan sewanya kepada seorang lain. Dalam sewa-menyewa kendaraan di sini memakai perjanjian konsensual, namun dalam Undang-Undang dibedakan akibat-akibatnya antara tertulis dan tidak tertulis (lisan). Pada sewa-menyewa secara tertulis terdapat pada Pasal 1570 dijelaskan bahwa jika sewa dibuat dengan tulisan, maka sewa itu berakhir demi hukum, apabila waktu yang ditentukan telah dilampaui tanpa dipelakukannya sesuatu pemberhentian untuk itu. Sedangkan dalam sewa-menyewa tidak tertulis (lisan) terdapat pada Pasal 1571 jika sewa tidak dibuat

\footnotetext{
${ }^{15}$ Wawancara dengan Ilham Fajar Rizki selaku Pimpinan CV. Mae Transl pada tanggal 2 November 2019.
} 
dengan tulisan, maka sewa itu tidak berakhir pada waktu yang ditentukan, melainkan jika pihak lain bahwa ia hendak menghentikan sewanya, dengan mengindahkan tenggang-tenggang waktu yang diharuskan menurut kebiasaan setempat ${ }^{16}$.

Penyelesaian Wanprestasi dalam sewa menyewa mobil pada CV Mae Trans Penyewa menyewakan ulang obyek kendaraan. Penyelesaiannya yaitu dengan ketentuan salah satunya menyewa mobil kepada pihak CV. Mae Trans selama 1 (satu) bulan atau 30 (tiga puluh) hari, yang mana mobil tersebut di sewa untuk di gunakan sebagai sarana transportasi demi kelancaran usaha yang baru didirikan oleh penyewa dengan hanya melakukan pembayaran secara penuh dari total harga sewa keseluruhan waktu sewa. Pihak CV. Mae Trans dalam hal ini merasa sangat dirugikan atas perbuatan yang dilakukan oleh penyewa yaitu harus menebusan barang sewa yaitu 1 (satu) unit mobil Daihatzu Xenia warna silver yang telah di sewakan ulang oleh penyewa kepada pihak ke 3 (tiga) dengan ketentuan pihak penyewa harus mengembalikan semua tunggakan dan kerugian atas uang sewa yang sudah disewakan kembali kepada orang lain, akan tetapi pihak penyewa juga sudah memiliki Iktikad baik dengan berjanji akan mengganti uang selama melebihi waktu sewa dan mengganti biaya atas sewa ulang yang dilakukannya dan akan berusaha mengembalikannya sebelum batas akhir yang di minta oleh pihak CV. Mae Trans ${ }^{17}$. Menurut hasil analisis yang di dapat penulis menyimpulkan bahwa penyelesaian yang dilakukan oleh pihak CV. Mae Trans dengan penyewa dilakukan bersama sama atau musyawarah guna mencapai suatu kesepakatan bersama guna tidak merugikan salah satu pihak karena menurut CV. Mae Trans pemecahan masalah apabila dilakukan secara bersama-sama dengan tidak merugikan salah satu pihak akan lebih baik guna untuk menjaga nama baik rental dengan tetap mempertahankan konsumennya agar tetap menjadi konsumen tetap dalam melakukan sewa untuk selanjutnya ${ }^{18}$.

Upaya hukum disini maksudnya adalah suatu tindakan atau upaya yang bertujuan untuk melindungi hak pihak yang menyewakan atau kreditor yang tidak dipenuhi oleh pihak penyewa atau debitor. Memberikan upaya apa saja yang dapat ditempuh oleh pihak yang menyewakan untuk mendapatkan hak-haknya yang semestinya didapatkan dan sesuai yang diperjanjikan oleh pihak penyewa.

Upaya hukum bagi pihak yang menyewakan itu artinya melindungi hak-hak dari pihak yang menyewakan atau pihak rental mobil. Apabila ada hak yang tidak dipenuhi atau dilanggar oleh pihak debitor atau pihak penyewa. Pihak yang menyewakan dapat meminta haknya kepada debitor melalui musyawarah terlebih dahulu. Apabila ternyata penyelesaian melalui musyawarah tidak berhasil maka pihak yang menyewakan dapat melakukan tindakan lebih tegas. Apabila sudah mempertegas pihak penyewa tetapi pihak penyewa tetap mangkir maka pihak rental mobil dapat melakukan teguran atau

\footnotetext{
${ }^{16}$ Zaeni Asyhadie. 2018. Hukum Keperdataan (dalam Perspektif Hukum Nasional, KUH Perdata (BW), Hukum Islam dan: Hukum Adat). Depok: Rajawali Pers. Cet.Ke-3.

${ }^{17}$ Wawancara dengan Ilham Fajar Rizki selaku Pimpinan CV. Mae Trans pada tanggal 2 November 2019.

${ }^{18}$ Ibid.
} 
somasi kepada penyewa mengenai prestasi atau kewajiban yang belum dilakukan, dan disertai dengan penarikan atas kendaraan yang disewakan apabila kendaraan tersebut masih ada ditangan pihak penyewa dan apabila ternyata setelah dilakukan somasi dan teguran tetapi pihak penyewa masih mangkir dan tidak melakukan prestasi atau kewajibannya, maka pihak yang menyewakan dapat melakukan gugatan atas perbuatan ingkar janji (wanprestasi) dan melakukan permohonan sita jaminan terhadap benda bergerak milik penyewa maupun benda bergerak lainnya sepanjang dapat menutupi seluruh kerugian tersebut.

Cara yang ditempuh oleh perusahaan rental mobil dalam hal terjadinya wanprestasi akan diupayakan penyelesaian secara musyawarah dan mufakat di kantor pusat perusahaan persewaan atau disebut sebagai pihak pertama, mengenai pembayaran dan jangka waktu tergantung pada hasil musyawarah. Atau perusahaan rental mobil dapat memberikan surat peringatan tertulis asal saja jangan sampai dengan mudah dipungkiri oleh si penyewa. Surat peringatan biasa tidak akan menimbulkan masalah jika penyewa menyadari kewajibannya dan memenuhi kewajibannya tersebut. Cara ini dilakukan karena pada hakekatnya perusahaan rental mobil dapat memberikan surat peringatan tertulis asal saja jangan sampai dengan mudah dipungkiri oleh si penyewa. Surat peringatan biasa tidak akan menimbulkan masalah jika penyewa menyadari kewajibannya dan memenuhi kewajibannya tersebut. Cara ini dilakukan karena pada hakekatnya perusahaan rental mobil ingin selalu menampilkan citra yang baik dan penuh pengertian sehingga penyewa dapat terus menjadi pelanggan yang bisa memberi keuntungan kepada perusahaan. Namun apabila seorang penyewa sudah diperingatkan atau sudah dengan tegas ditagih janjinya, tetapi tetap tidak memenuhi prestasi yang diperjanjikan, maka dalam hal ini tidak diperlukan lagi peringatan karena ia telah dinyatakan melakukan wanprestasi. Akibat hukum bagi penyewa yang telah melakukan wanprestasi adalah dikenakan sanksi berikut ini: ${ }^{19}$

1. Membayar kerugian yang diderita oleh perusahaan persewaan atau dengan singkat dinamakan ganti rugi. Kerugian tersebut berupa kehilangan keuntungan yang sudah dibayangkan dan dihitung oleh perusahaan sewa. Ketentuan tentang ganti rugi ini diatur dalam pasal $1243 \mathrm{KUH}$ Perdata sampai dengan $1252 \mathrm{KUH}$ Perdata.

2. Pembatalan perjanjian atau juga dinamakan pemecahan perjanjian. pembatalan perjanjian bertujuan membawa kedua belah pihak kembali kepada keadaan sebelum perjanjian diadakan. Kalau satu pihak sudah menerima sesuatu dari pihak yang lain, baik uang maupun barang, maka itu harus dikembalikan. Masalah pembatalan perjanjian terdapat pengaturannya pada pasal $1266 \mathrm{KUH}$ Perdata.

\footnotetext{
${ }^{19}$ Pradnyaswari, 2013, Upaya hukum penyelesaian wanprestasi dalam perjanjian sewa menyewa kendaraan, Jurnal Advokasi Fakultas Hukum Universitas Mahasaraswati Vol 3 No 2 hlm 14
} 
3. Pengalihan resiko. Resiko beralih kepada penyewa sejak terjadinya wanprestasi (Pasal 1237 ayat (2) KUHPerdata). Ketentuan ini hanya berlaku bagi perjanjian untuk memberikan sesuatu.

4. Membayar biaya perkara, kalau sampai diperkarakan dimuka hakim.

5. Memenuhi perjanjian jika masih dapat dilakukan, atau pembatalan perjanjian disertai dengan pembayaran ganti kerugian, hal ini tercantum dalam pasal 1267 KUHPerdata.

Dari akibat-akibat hukum tersebut di atas, perusahaan sewa dapat memilih diantara beberapa kemungkinan tuntutan terhadap penyewa yaitu:

1. Dapat menuntut pemenuhan perjanjian

2. Pemenuhan perjanjian/ prestasi disertai dengan ganti kerugian

3. Menuntut ganti kerugian saja

4. Menuntut pembatalan perjanjian lewat hakim

5. Menuntut pembatalan perjanjian disertai ganti kerugian.

Kewajiban membayar ganti rugi tersebut tidak timbul seketika terjadi kelalaian, melainkan baru efektif setelah penyewa dikatakan lalai dan tetap tidak melaksanakan prestasinya. Hal ini diatur dalam pasal 1243 KUH Perdata, sedangkan bentuk pernyataan lalai tersebut diatur dalam pasal 1238 KUHPerdata yang pada pokoknya menyatakan $:^{20}$

1. Pernyataan lalai tersebut harus berbentuk surat perintah atau akta lain yang sejenis, yaitu suatu salinan daripada tulisan yang telah dibuat lebih dahulu oleh juru sita dan diberikan kepada yang bersangkutan.

2. Berdasarkan kekuatan perjanjian itu sendiri.

3. Jika teguran kelalaian sudah dilakukan barulah menyusul peringatan yang biasa disebut somasi.

Dapat dikatakan, apabila tejadi keadaan memaksa (force majeure) yang diluar kemampuan penyewa, penyewa tidak bersalah. Penyewa kendaraan bermotor dapat dituntut untuk memenuhi seluruh kewajibannya bila dilihat karena kesalahan penyewa, baik karena kesengajaan maupun karena kelalaian. Pihak yang menyewakan Dapat menuntut pemenuhan perjanjian/ prestasi disertai dengan ganti kerugian, menuntut ganti kerugian saja, menuntut pembatalan perjanjian lewat hakim dan menuntut pembatalan perjanjian disertai ganti kerugian.

Upaya yang ditempuh oleh perusahaan rental mobil dalam hal terjadinya wanprestasi akan diupayakan penyelesaian secara musyawarah dan mufakat di kantor

\footnotetext{
${ }^{20}$ Pradnyaswari,2 013, Upaya hukum penyelesaian wanprestasi dalam perjanjian sewa menyewa kendaraan, Jurnal Advokasi Fakultas hukum Universitas Mahasaraswati Vol 3 No 2 hlm 15
} 
pusat perusahaan persewaan atau disebut sebagai pihak pertama, mengenai pembayaran dan jangka waktu tergantung pada hasil musyawarah, atau perusahaan rental mobil dapat memberikan surat peringatan tertulis asal saja jangan sampai dengan mudah dipungkiri oleh si penyewa. Surat peringatan biasa tidak akan menimbulkan masalah jika penyewa menyadari kewajibannya dan memenuhi kewajibannya tersebut.

Pasal 1548 KUH Perdata menyatakan bahwa hubungan hukum sewa menyewa adalah berdasarkan suatu perjanjian, baik dari perjanjian untuk memberikan kenikmatan dan suatu barang, perjanjian untuk menikmatinya selama waktu tertentu, dan perjanjian untuk memberikan pembayaran atas kegiatan menikmati barang tersebut. Apabila ternyata dari salah satu pihak tidak dapat memenuhi perjanjian tersebut atas prestasinya, maka pihak yang menyewakan dapat melakukan peneguran secara tertulis atau yang biasa dikenal somasi dengan jangka waktu yang cukup.Apabila ternyata pihak penyewa tidak mengindahkan teguran atau somasi tersebut maka pihak yang merasa dirugikan dapat melakukan gugatan ke Pengadilan.

Berkaitan tentang upaya hukum bagi pemilik mobil dapat ditemukan pada setiap pembuatan surat perjanjiannya, yaitu perjanjian sewa-menyewa mobil. Menurut Pasal 1338 ayat (1) KUHPerdata menyatakan bahwa perjanjian ini dapat dijadikan UndangUndang bagi pihak yang membuatnya asalkan telah memenuhi syarat sahnya perjanjian. Jika dalam perjanjian sewa menyewa itu pihak penyewa tidak melakukan prestasinya maka pihak penyewa tersebut telah melakukan wanprestasi. Sehingga, pihak yang menyewakan dapat menuntut atau melakukan gugatan ke pengadilan apabila pihak penyewa tidak dapat menyelesaikan masalahnya dengan musyawarah secara kekeluargaan. Pasal ini dapat digunakan sebagai dasar gugatan ke Pengadilan apabila kreditor tidak dipenuhi haknya oleh debitor.

Sebaiknya dalam pelaksanaan perjanjian sewa menyewa antara pihak rental dengan pihak penyewa dibuat secara otentik agar kekuatan dalam pembuktiannya kuat. Namun dalam kenyataanya perjanjian sewa menyewa ini dilakukan dengan bentuk akta dibawah tangan. Perjanjian otentik seharusnya dibuat di hadapan notaris, karena akta otentik pasti akan dianggap kuat dalam pembuktiannya. Selain itu ada cara lain untuk memberikan kekuatan sebuah akta dibawah tangan, yaitu akta dibawah tangan dilegalisasi oleh Notaris. Akta yang dibuat dibawah tangan yang dilegalisasi tersebut memiliki pembuktian yang kuat. Jadi kesimpulannya perlindungan bagi pemilik mobil adalah surat perjanjian sewa menyewa yang otentik atau dibawah tangan yang dilegalisasi.

\section{Simpulan}

\subsection{Simpulan}

Perjanjian sewa menyewa mobil yang menimbulkan Wanprestasi di Kabupaten Bantul yaitu: 
a. Penyewa merusak objek sewa. Penyelesaian Wanprestasi dalam sewa menyewa mobil pada CV. GH Tour and Travel di lakukan dengan cara meminta uang ganti sewa atas biaya servis kendaraan selama berada dalam masa perbaikan

b. Penyewa terlambat mengembalikan objek kendaraan. Pada CV. Cahya Tour dalam menyelesaikan sengketa wanprestasi di lakukan dengan cara memberikan biaya denda kepada pihak penyewa, perhitungan untuk keterlambatan dihitung setiap jam nya dan besarnya denda adalah $10 \%$ dari harga sewa mobil yang disewa

c. Penyewa menyewakan ulang obyek kendaraan. Penyelesaian yang dilakukan oleh pihak CV. Mae Trans dengan penyewa dilakukan dengan meminta biaya kerugian dan meminta uang hasil dari penyewa yang mengulang sewakan obyek sewa kepada pihak ketiga.

\subsection{Saran}

a. Berdasarkan kesimpulan diatas dapat disarankan sebagai berikut:

b. Bagi pihak yang menyewa mobil sebaiknya lebih hati-hati dalam memakai mobil sewaannya sehingga tidak terjadi kerusakan terhadap mobil tersebut.

c. Bagi pihak yang menyewakan seharusnya lebih teliti memberikan mobil sewaannya kepada pihak penyewa dan lebih teliti dalam membuat suatu perjanjian yang telah disepakati bersama.

\section{Daftar Pustaka}

\section{Buku}

Abdulkadir Muhammad. (2004). Hukum dan Penelitian Hukum Cet-1. Bandung: PT Citra Aditya Bakti.

Langgeng Wahyu Santosa. (2016). Keistimewaan Yogyakarta dari Sudut Pandang Geomorfologi. Yogyakarta: Gadjah Mada University Press.

Peter Mahmud Marzuki. (2008). Penelitian Hukum. Jakarta: Kencana.

Sugiyono. (2014). Metode Penelitian Kuantitatif Kualitatif dan R\&D. Bandung: Alfabeta

Zaeni Asyhadie. (2018). Hukum Keperdataan (dalam Perspektif Hukum Nasional, KUH Perdata (BW), Hukum Islam dan Hukum Adat. Depok: Rajawali Pers. Cet.Ke-3.

Subekti. (1984). Hukum Perjanjian. Jakarta: Intermasa

\section{Jurnal}

Pradnyaswari. (2013). "Upaya Hukum Penyelesaian Wanprestasi Dalam Perjanjian Sewa Menyewa Kendaraan". Jurnal Advokasi Fakultas Hukum Universitas Mahasaraswati Vol. 3 No. 2 
Media of Law and Sharia, Vol. 1, No. 2, 2020, 106-118

\section{Regulasi}

Kitab Undang-Undang Hukum Perdata (KUH Perdata)

\section{Wawancara}

Ilham. (2019). "Wawancara Pimpinan CV. GH Tour and Travel".

Albertus Okki Setiawan. (2019). "Wawancara Pimpinan CV. Cahaya Tour".

Ilham Fajar Rizki. (2019). "Wawancara Pimpinan CV. Mae Transl”. 